\title{
Very low levels of high density lipoprotein cholesterol in four sibs of a family with non-neuropathic Niemann- Pick disease and sea-blue histiocytosis
}

\author{
Marcos Borato Viana, Roberto Giugliani, Virginia Hora Rios Leite, Maria Luiza Barth, \\ Chandra Lekhwani, Christina Mary Slade, Anthony Fensom
}

\begin{abstract}
Very low serum levels of high density lipoprotein cholesterol ranging from 8.6 to $13.9 \mathrm{mg} / \mathrm{dl}$ were detected in four out of $\mathbf{1 2}$ sibs of a Brazilian kindred with the non-neuropathic form of Niemann-Pick disease. Hepatosplenomegaly, interstitial infiltration of the lungs, absence of neurological signs, sea-blue histiocytes in the bone marrow and liver, and high values for serum acid phosphatase (18 to $32 \mathrm{U} / \mathrm{l}$ ) were common to all affected children. Leucocyte acid sphingomyelinase activity ranged from 3.6 to $6.5 \%$ of mean control values, and fibroblast activity from 9 to $13 \%$ of mean controls. The parents had low-normal levels. The relationship between these findings is unclear and deserves further investigation.
\end{abstract}

The sea-blue histiocyte is a macrophage that contains numerous cytoplasmic granules of varying sizes which stain blue with Romanowsky dyes.' The term 'syndrome of the sea-blue histiocyte' was introduced by Silverstein $e t a l^{2}$ to describe a spectrum of diseases

Department of Pediatrics, Federal University of Minas Gerais, Brazil.

M B Viana

Department of Biochemistry, Medical Genetics Unit, Federal University of Rio Grande do Sul, Brazil.

R Giugliani, M L Barth

Department of Pathologic Anatomy and Legal Medicine, Federal University of Minas Gerais, Brazil.

V H R Leite

Paediatric Research Unit, Division of Medical \& Molecular Genetics, UMDS, Guy's Hospital, London SE1 9RT.

C Lekhwani, C M Slade, A Fensom

Correspondence to Dr Viana, Departamento de Pediatria da UFMG, Avenida Alfredo Balena, 190 Belo Horizonte, CEP 30.130, Brazil.

Received for publication 4 October 1989

Revised version accepted for publication 7 February 1990 varying from a relatively benign mild purpura secondary to thrombocytopenia to a progressive hepatic cirrhosis, hepatic failure, and death. Patients had characteristic sea-blue histiocytes in bone marrow, or bone marrow and liver. They were considered to have the primary form of the syndrome.

Sea-blue histiocytes may also be found in the bone marrow in many well defined diseases: porphyria, ${ }^{3}$ familial lecithin:cholesterol acyl transferase deficiency, ${ }^{4}$ iron deficient anaemia, ${ }^{5}$ leukaemia, ${ }^{6}$ idiopathic thrombocytopenic purpura, ${ }^{7}$ and cholesterol ester storage disease, ${ }^{8}$ among others. Remarkably, many cases initially considered to be clear cut examples of the primary sea-blue histiocyte syndrome were ultimately proven to be variants of NiemannPick disease. ${ }^{9-14}$ Golde $e t a l^{9}$ were the first to show that the activity of sphingomyelinase was low in the extracts of fibroblasts of three sibs formerly reported as examples of the syndrome.

We present our studies on a large Brazilian kindred in which four sibs were found to have sea-blue histiocytes, sphingomyelinase deficiency, and very low serum levels of high density lipoprotein cholesterol.

\section{Family report}

A large Brazilian kindred composed of father, mother, 12 children, and two grandchildren was investigated because one of the children, a 7 year old boy, was found to have massive hepatosplenomegaly since infancy. There was no consanguinity as far as the parents were aware. Four out of the 12 children, now aged $4,8,17$, and 23 years (fig 1 ), show a very similar clinical and biochemical picture: massive hepatosplenomegaly, short stature for age, bilateral interstitial pulmonary infiltration with low $\mathrm{Po}_{2}$ in three of them, and high levels of serum acid phosphatase (32, 22,19 , and $18 \mathrm{U} / \mathrm{l}$ respectively for the affected children, and $7 \mathrm{U} / \mathrm{l}$ for the father). They show normal mental development, normal retina and macula, and normal blood counts and platelet aggregation. Bone marrow aspirates showed many sea-blue histiocytes in 
all affected sibs. Serum aspartate/alanine aminotransferase activities were $53 / 24,31 / 29$, and $55 / 60 \mathrm{U} / 1$ for the last three children. Serum albumin concentration ranged from 33 to $49 \mathrm{~g} / \mathrm{l}$ in the four children. Bilirubin concentration was normal in all affected sibs and

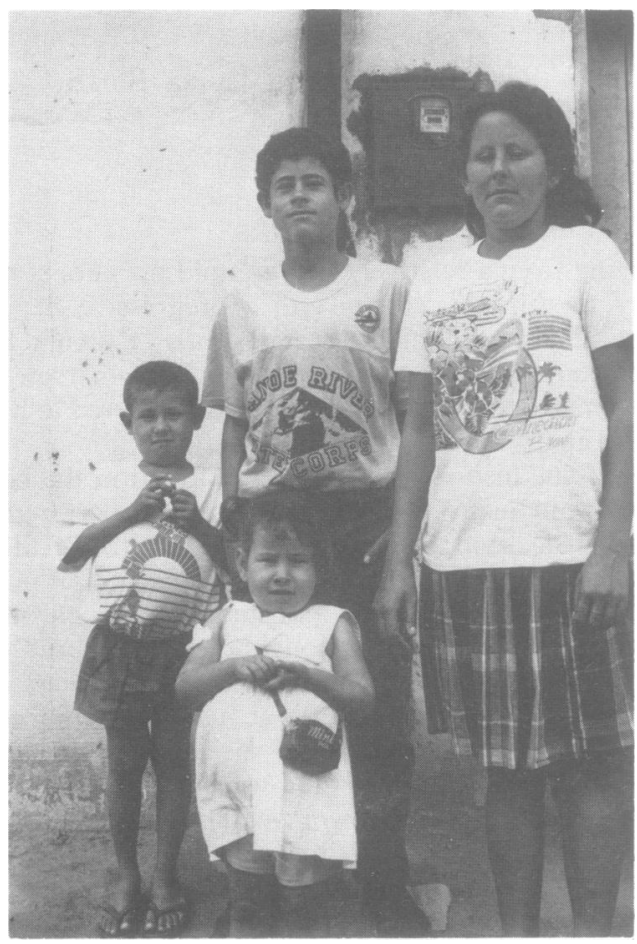

Figure 1 The four affected children with the sea-blue histiocyte syndrome/Niemann-Pick disease. The photograph was taken in $\mathcal{F}$ uly 1988. Note the protuberant abdomens of the two younger children. prothrombin activity ranged from 60 to $70 \%$ of simultaneous controls. Lactic dehydrogenase and alkaline phosphatase were both within the reference values for age in all four children. The liver biopsy performed in the four children showed slight portal fibrosis and sea-blue histiocytes in the portal space and also intralobularly. Foamy hepatocytes were observed in the two older sibs. Both parents, seven out of the other eight children investigated, and two grandchildren, born to an unaffected daughter, were clinically normal, and no sea-blue histiocytes were observed in their bone marrow aspirates.

Histochemical staining was performed on the bone marrow aspirate slides from the 23 year old girl. The sea-blue histiocyte granules were coloured deep blue by the May-Gruenwald-Giemsa stain, red by the long Ziehl-Neelsen method, black by the Sudan-black technique, and light red by the PAS; there was no stain with the Prussian blue and peroxidase reactions. The specific iron haematoxylin method preceded by alkaline hydrolysis, described by Elleder and Lojda ${ }^{15}$ for the detection of sphingomyelin, stained the histiocytic cytoplasm black (fig 2). The chloroformmethanol lipid extracted control smear was negative. The cytoplasmic material was also birefringent and had a bright yellow autofluorescence in the unstained smear. These findings taken together are suggestive of sphingomyelin and ceroid accumulation in the histiog cytes.

\section{Laboratory investigations METHODS}

High density lipoprotein cholesterol was determined by the phosphotungstate-magnesium method, ${ }^{16}$ and plasma concentrations of apolipoproteins by radial immunodiffusion using Behring plates.

Leucocytes were separated from heparinised blood

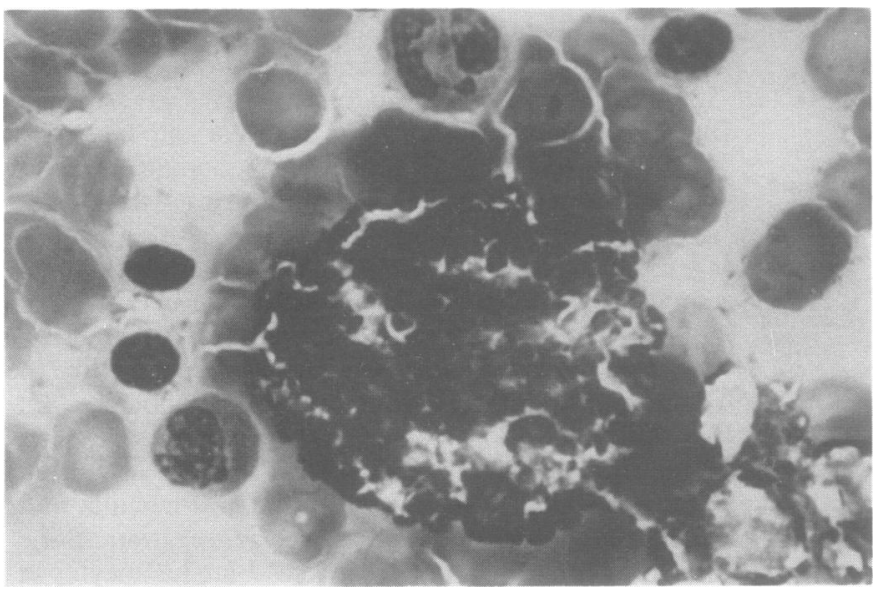

Figure 2 Bone marrow of sib 4 stained by the iron haematoxylin method preceded by alkaline hydrolysis. The cytoplasm of the histiocytes shows coarse black granules.

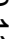

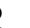


after dextran sedimentation, ${ }^{17}$ and skin fibroblasts cultured by standard techniques using Ham's F10 medium containing $10 \%$ fetal calf serum. Cell strain GM3252 from a patient with Niemann-Pick disease type B was obtained from the Human Genetic Mutant Cell Repository, Camden, New Jersey, USA. For enzyme assays, leucocytes and fibroblasts were suspended in water, disrupted by sonication using an MSE 150W instrument, and taken for analysis without centrifugation.

Sphingomyelinase was assayed using an incubation mixture containing $30 \mathrm{nmol}\left[\mathrm{N}\right.$-methyl- $\left.{ }^{14} \mathrm{C}\right]$-sphingomyelin (NEN; approx $1500 \mathrm{dpm} / \mathrm{nmol}$ ), $25 \mu \mathrm{g}$ sodium taurocholate, $125 \mu \mathrm{g}$ Triton X100, $10 \mu \mathrm{mol}$ sodium

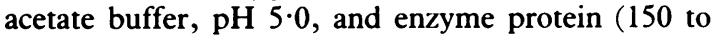
$200 \mu \mathrm{g}$ for leucocytes, 20 to $50 \mu \mathrm{g}$ for fibroblasts) in a final volume of $100 \mu \mathrm{l}$. Tubes were incubated at $37^{\circ} \mathrm{C}$ with gentle shaking for four hours (leucocytes) or one hour (fibroblasts). They were placed on ice and $10 \%$ bovine serum albumin $(100 \mu \mathrm{l})$ and $10 \%$ trichloroacetic acid $(750 \mu \mathrm{l})$ was added to each. After centrifugation, a portion $(500 \mu \mathrm{l})$ of the supernatant was transferred to a scintillation vial and counted using Aquasol.

Thermal stability studies of fibroblast sphingomyelinase activity at $50^{\circ} \mathrm{C}$ were carried out using a method based on that of Schneider et al, ${ }^{18}$ but with detergent concentrations adjusted to those of our standard assay. Cell pellets were sonicated in $25 \mathrm{mmol} / \mathrm{l}$ citrate phosphate buffer, $\mathrm{pH} 6.0$, containing Triton X100 $(2 \mathrm{mg} / \mathrm{ml})$ and sodium taurocholate $(0 \cdot 4 \mathrm{mg} / \mathrm{ml})$. After incubation for $2,5,10,20,30$, or 60 minutes at $50^{\circ} \mathrm{C}$, sphingomyelinase was measured as above.

Acid esterase, $\beta$-galactosidase, and $\beta$-glucosidase were assayed in leucocyte and fibroblast extracts using 4-methylumbelliferyl substrates, and protein was determined by the method of Lowry et al. ${ }^{19}$

\section{Results}

SERUM LIPIDS

The serum lipid pattern for the affected sibs and the father is summarised in table 1. HDL cholesterol was consistently low in the four affected children, contrasting with a normal value for their father. Apolipo-

Table 1 Serum lipid pattern in a family with the sea-blue histiocyte syndrome/Niemann-Pick disease.

\begin{tabular}{lcccr}
\hline & $\begin{array}{c}\text { Age }(\mathbf{y}) / \\
\text { sex }\end{array}$ & $\begin{array}{c}\text { Total } \\
\text { cholesterol } \\
(\mathbf{m g} / \mathrm{dl})\end{array}$ & $\begin{array}{c}\text { Triglycerides } \\
(\mathrm{mg} / \mathrm{dl})\end{array}$ & $\begin{array}{c}\text { HDL } \\
\text { cholesterol } \\
(\mathrm{mg} / \mathrm{dl})\end{array}$ \\
\hline Sib 1 & $2 / \mathrm{F}$ & $306(70-175)$ & $396(10-140)$ & $9 \cdot 4(30)$ \\
Sib 2 & $7 / \mathrm{M}$ & $227(70-175)$ & $300(10-140)$ & $10 \cdot 7(40)$ \\
Sib 3 & $16 / \mathrm{M}$ & $187(132-183)$ & $134(10-140)$ & $13 \cdot 9(35)$ \\
Sib 4 & $22 / \mathrm{F}$ & $250(132-217)$ & $240(10-140)$ & $8 \cdot 6(35)$ \\
Father & $55 / \mathrm{M}$ & $156(168-260)$ & $36(10-190)$ & $46.7(30)$ \\
\hline
\end{tabular}

Figures in parentheses represent the normal ranges for age and sex (total cholesterol and triglycerides) or the 5th centile according to Herbert et al ${ }^{20}$ (HDL cholesterol). protein concentrations for two of the children and the parents are shown in table 2 .

\section{ENZYME STUDIES}

Since many patients with the sea-blue histiocyte syndrome have been shown to be cases of chronic Niemann-Pick disease, ${ }^{9-14}$ the activity of acid sphingomyelinase was measured in leucocytes and cultured skin fibroblasts from the four affected sibs, the parents, and seven of the eight unaffected children (table 3). All four affected children were found to have low levels in both leucocytes and fibroblasts. The residual activities in the leucocytes were lower than in fibroblasts, but the former values may have been underestimated since the blood samples were in transit for four days at $0^{\circ} \mathrm{C}$ between the remote region of Brazil where the family lives and London before isolation of the cells. Control experiments indicated that under these conditions normal leucocytes lose 50 to $65 \%$ of their sphingomyelinase activity when assayed by our method. The residual activities recorded in fibroblasts ( 9 to $13 \%$ of normal control mean) are probably a more meaningful assessment of the degree of sphingomyelinase deficiency. In comparison with other Niemann-Pick patients studied in our laboratory, this deficiency was less marked than that in three type A patients $(0.4$ to $0.8 \%$ of control mean), and three type B ( $2 \cdot 5 \%$ for strain GM 3252 and $4.0 \%$ and $5.0 \%$ for two further patients), but more severe than in 10 type $C$ patients ( 18 to $45 \%$ of control mean). Mixing experiments using extracts of the patients' fibroblasts and normal cells led to the expected recovery of sphingomyelinase activity, excluding the possibility of an inhibitor as the cause of the low activity.

Sphingomyelinase activities in leucocytes from the parents and four of the unaffected sibs were low (10 to $52 \%$ of normal mean, table 3 ), although these values may be underestimates for the reason noted above. Fibroblast values were not sufficiently deficient to provide strong evidence for heterozygosity in either parent or any unaffected sib when expressed as a percentage of the normal mean; in particular, the mother's activity was $82 \%$ of the normal mean despite her low leucocyte activity. When fibroblast results were expressed as a percentage of the mean of three

Table 2 Apolipoprotein concentrations in plasma from two of the patients and their parents.

\begin{tabular}{lccc}
\hline & $\begin{array}{c}\text { APO AI } \\
(\mathrm{g} / \mathrm{l})\end{array}$ & $\begin{array}{c}\text { Total APO A } \\
(\mathrm{g} / \mathrm{l})\end{array}$ & $\begin{array}{c}\text { APO B } \\
(\mathrm{g} / \mathrm{l})\end{array}$ \\
\hline Sib 3 & $\mathbf{0 . 2 9}$ & 0.63 & $1 \cdot 25$ \\
Sib 4 & 0.44 & 0.75 & $2 \cdot 29$ \\
Father & $0 \cdot 78$ & 1.25 & 0.81 \\
Mother & 0.90 & 1.45 & 1.32 \\
Reference ranges & $0.90-2 \cdot 10$ & $1 \cdot 60-3.30$ & $0.45-1.60$ \\
\hline
\end{tabular}


Table 3 Sphingomyelinase activity in a family with the sea-blue histiocyte syndrome/Niemann-Pick disease.

\begin{tabular}{|c|c|c|c|c|c|c|}
\hline \multirow[b]{3}{*}{ Patient } & \multirow[b]{3}{*}{ Age $(y) / \operatorname{sex}$} & \multicolumn{5}{|c|}{ Sphingomyelinase activity } \\
\hline & & \multicolumn{2}{|c|}{ Leucocytes } & \multicolumn{3}{|c|}{ Fibroblasts } \\
\hline & & Activity & $\begin{array}{c}\% \text { overall } \\
\text { control mean }\end{array}$ & Activity & $\begin{array}{l}\% \text { overall } \\
\text { control mean }\end{array}$ & $\begin{array}{c}\% \text { simultaneous } \\
\text { controls }\end{array}$ \\
\hline $\begin{array}{l}\text { Affected sib } 1 \\
\text { Affected sib } 2 \\
\text { Affected sib } 3 \\
\text { Affected sib } 4 \\
\text { Father } \\
\text { Mother } \\
\text { Unaffected sib } 1 \\
\text { Unaffected sib } 2 \\
\text { Unaffected sib } 3 \\
\text { Unaffected sib } 4 \\
\text { Unaffected sib } 5 \\
\text { Unaffected sib } 6 \\
\text { Unaffected sib } 7\end{array}$ & $\begin{array}{c}4 / \mathrm{F} \\
8 / \mathrm{M} \\
17 / \mathrm{M} \\
23 / \mathrm{F} \\
55 / \mathrm{M} \\
46 / \mathrm{F} \\
2 / \mathrm{M} \\
10 / \mathrm{F} \\
12 / \mathrm{M} \\
14 / \mathrm{F} \\
18 / \mathrm{F} \\
20 / \mathrm{F} \\
26 / \mathrm{M}\end{array}$ & $\begin{array}{l}0.14 \\
0.14 \\
0.16 \\
0.09 \\
0.91 \\
0 \cdot 25 \\
0.67 \\
2.95 \\
2 \cdot 16 \\
1 \cdot 01 \\
2 \cdot 78 \\
0.88 \\
1 \cdot 28\end{array}$ & $\begin{array}{r}5 \cdot 6 \\
5 \cdot 6 \\
6 \cdot 5 \\
3 \cdot 6 \\
37 \\
10 \\
27 \\
119 \\
87 \\
41 \\
112 \\
36 \\
52\end{array}$ & $\begin{array}{l}37 \\
33 \\
29 \\
40 \\
250 \\
261 \\
226 \\
378 \\
357 \\
442 \\
408 \\
254 \\
440\end{array}$ & $\begin{array}{r}12 \\
10 \\
9 \\
13 \\
79 \\
82 \\
71 \\
120 \\
113 \\
140 \\
129 \\
80 \\
139\end{array}$ & $\begin{array}{c}10 \\
9 \\
7 \cdot 7 \\
10 \\
66 \\
69 \\
60 \\
100 \\
94 \\
117 \\
108 \\
67 \\
116\end{array}$ \\
\hline Normal ranges & & $\begin{array}{c}0 \cdot 74-7 \cdot 01 \\
(\mathrm{n}=72) \\
\text { Mean } 2 \cdot 47 \\
(\mathrm{SD} 1 \cdot 33)\end{array}$ & & $\begin{array}{c}161-653 \\
(n=53) \\
\text { Mean 315 } \\
(\text { SD 117) }\end{array}$ & & \\
\hline
\end{tabular}

Enzyme activities are given in $\mathrm{nmol} / \mathrm{h} / \mathrm{mg}$ protein.

Table 4 Half lives of sphingomyelinase activities in fibroblasts.

\begin{tabular}{lc}
\hline Cell strain & Half life at $50^{\circ} \mathrm{C}(\mathrm{min})$ \\
\hline Affected sib 2 & 62 \\
Affected sib 3 & 69 \\
Father & 75 \\
Mother & 84 \\
GM3252 & 65 \\
Control (1) & 66 \\
Control (2) & 65 \\
\hline
\end{tabular}

simultaneous control strains to try to improve heterozygote identification ${ }^{21}$ (table 3 , final column), lower residual activities were obtained for the parents $(66$ and $69 \%$ ). However, residual leucocyte and fibroblast values still only correlated for five of the seven unaffected sibs (Nos 1, 2, 3, 5, and 6).

Studies of the heat stability of fibroblast sphingomyelinase activity (table 4) indicated no significant difference in lability between two of the patients investigated, the Niemann-Pick strain GM3252, and controls. Parental enzyme stability was slightly increased over controls, but not markedly.

Acid esterase (4-methylumbelliferyl palmitate substrate), $\beta$-glucosidase, and $\beta$-galactosidase activities were normal in leucocytes and cultured fibroblasts from all family members (data not shown).

\section{Discussion}

The four sibs with sea-blue histiocyte syndrome described in this paper were shown to have deficient sphingomyelinase activity consistent with a diagnosis of Niemann-Pick disease. Clinically they should probably be classified as type $B$ although the residual activity in their fibroblasts was higher than found inco three other cases of type B studied by us. Although क comparisions based on slightly different methods $\overrightarrow{0}$ should be made cautiously, the residual activity, expressed as a percentage of the control mean, w\$s also higher than that reported by Vanier $e t a l^{22}$ for $\$$ type B patients, where it ranged from $0.33 \%$ to $8 \overline{8}$ (mean $4 \%$ ).

The lability of fibroblast sphingomyelinase activity in our patients was not increased, distinguishing them $\triangle$ biochemically from three patients in two families $\overrightarrow{\overrightarrow{0}}$ where fibroblast sphingomyelinase activity was more $\exists$ heat labile than in controls. ${ }^{18}$ These patients, who were designated Niemann-Pick disease type $F$, did, however, show some clinical resemblance to our patients. Similarly, the reported fibroblast sphingomyelinase activity in three sibs ranged from 11 to $16 \%$ 웅 of the control mean. ${ }^{18}$

The disease in our patients was probably inherited $\delta$ as an autosomal recessive trait, since children of both $₹$ sexes were affected and the parents had low-normal $\subseteq$ sphingomyelinase activities in fibroblasts and the mother's leucocyte activity was below the normal range. Diminution in enzyme activity in parental fibroblasts was more notable when expressed as a mean of three simultaneously assayed controls rather $N$ than as a mean of our overall control range.

Low levels of HDL cholesterol are related to a higher incidence of atherosclerotic arterial changes but we have not up to now been able to detect any abnormality in the four patients under investigation. $\stackrel{\mathcal{D}}{\rightarrow}$

There have been previous reports of low levels of $T$ serum HDL cholesterol in Niemann-Pick disease similar to those found in our patients. Fredrickson ${ }^{23}$ found levels of 13,13 , and $24 \mathrm{mg} / \mathrm{dl}$ in three patients 
(probably types $\mathrm{A}, \mathrm{A}$, and $\mathrm{C}$, respectively), while values of $19 \mathrm{mg} / \mathrm{dl}^{24}$ and $21 \mathrm{mg} / \mathrm{dl}^{25}$ were reported by other workers for two type B patients. The low concentration of apolipoprotein AI observed in two affected children, also reported by Aubert et al, ${ }^{24}$ suggests that the HDL concentration itself is low and not only its cholesterol fraction.

Many clinical conditions may be associated with low HDL cholesterol concentration. Obstructive liver disease, marked parenchymal hepatic dysfunction, dysglobulinaemias, malnutrition, and severe hypertriglyceridaemias were not present in any sib of the reported family. Liver dysfunction was very mild in that the serum bilirubin and albumin concentration were within the reference values for age, whereas the aminotransferases and prothrombin time were only mildly abnormal. Cirrhosis was not present. Low plasmatic activity of the liver enzyme lecithincholesterol acyltransferase (LCAT) may be associated with lipoprotein abnormalities in liver diseases. LCAT activity was not measured in our patients, but would be expected to be high because there is a strong inverse correlation between the LCAT level and bilirubin concentration, as liver dysfunction progresses. $^{26}$ The triglyceridaemia was only modestly raised in three out of four sibs. In patient 3 (table 1) the value was normal and the simultaneous HDL cholesterol concentration was very low $(8.6 \mathrm{mg} / \mathrm{dl})$.

It is noteworthy that in two other lysosomal storage diseases low serum HDL cholesterol concentration may be found. Five patients with Gaucher's disease were reported to have values that ranged from 15 to 30 $\mathrm{mg} / \mathrm{dl} .{ }^{27}$ Three patients with cholesterol ester storage disease were also found to have low HDL cholesterolaemia. ${ }^{28}$ Taken together these observations suggest that the low HDL cholesterol and apolipoprotein AI concentration in the affected sibs of our family might be secondary phenomena to the basic disturbance of lysosomal sphingomyelinase deficiency. Further research seems warranted since the disease may serve as a naturally occurring model for studying relationships between lipoprotein metabolism and enzymatic function. Equally, there may be relevance to the pathogenesis of the atherosclerotic diseases.

The relationship between sphingomyelinase deficiency and lipoprotein metabolism has been studied by some researchers. Maziere et $a^{29}$ found that cultured skin fibroblasts from Niemann-Pick disease type $A$ had an increase in cholesterol synthesis from $\left[{ }^{14} \mathrm{C}\right]$-acetate and a decrease in $\left[{ }^{14} \mathrm{C}\right]$-oleic acid incorporation into cholesterol esters. $\left[{ }^{125} \mathrm{I}\right]$-low density lipoprotein (LDL) binding was significantly reduced in three of four cases investigated.

Pentchev et $a l^{30}$ reported a deficiency in the esterification of LDL derived cholesterol in fibroblasts from subjects with Niemann-Pick disease type $C$ and a partial deficiency in heterozygotes. In addition, they observed that affected fibroblasts, apparently mediated by the specific LDL receptor pathway, internalised an excess of total cholesterol LDL. They postulated that these findings would be linked to the basic genetic defect in Niemann-Pick disease type C.

We have tentatively classified our patients as type B Niemann-Pick disease. Further clinical and morphological assessments and biochemical characterisation of the presumed variant are in progress.

We thank Dr Geraldo Lustosa for assaying the HDL cholesterol at his laboratory in Belo Horizonte, Brazil, and Dr Raul Maranhao, from Sao Paulo University, for the apolipoprotein determinations. The work of $\mathrm{CL}, \mathrm{CMS}$, and AF is supported by the Department of Health, and the Paediatric Research Unit by the Spastics Society.

1 Moeschlin S. Die Milzpunktion: Technik, diagnostische und hamatologische Ergebnisse. Basle: B Schwabe, 1947:37-8.

2 Silverstein MN, Ellefson RD, Ahern EJ. The syndrome of the sea-blue histiocyte. N Engl 7 Med 1970;282:1-4.

3 Ghosh ML. The sea-blue histiocyte syndrome with hepatic porphyria and infectious mononucleosis. F Clin Pathol 1972;25: 945-6.

4 Jacobsen CD, Gjone E, Hovig T. Sea-blue histiocytes in familial lecithin:cholesterol-acyl-transferase deficiency. Scand $\mathcal{J}$ Haematol 1972;9:106-13.

5 Hamilton HE, Sheets RF, Fisher IK. The sea-blue histiocyte (SBH) viewed as a definitive cell unable to process erythrocyte lipid-a morphologic study. F Lab Clin Med 1971;78:841-2.

6 Dosik H, Rosner F, Sawitsky A. Acquired lipidosis: Gaucher-like cells and 'blue cells' in chronic granulocytic leukemia. Semin Hematol 1972;9:309-16.

7 Chandra P, Rosner F, Sawitsky A. Sea-blue histiocytes in thrombocytopenic purpura. Ann Intern Med 1973;79:901-2.

8 Besley GTN, Broadhead DM, Lawlor E, et al. Cholesterol ester storage disease in an adult presenting with sea-blue histiocytosis. Clin Genet 1984;26:195-203.

9 Golde DW, Schneider EL, Bainton DF, et ul. Pathogenesis of one variant of sea-blue histiocytosis. Lab Invest 1975;33:371-8

10 Long RG, Lake BD, Pettit JE, Scheuer PJ, Sherlock S. Adult Niemann-Pick disease: its relationship to the syndrome of the sea-blue histiocyte. Am $\mathcal{F}$ Med 1977;62:627-35.

11 Wenger DA, Barth G, Githens JH. Nine cases of sphingomyelin lipidosis, a new variant in Spanish-American children. Juvenile variant of Niemann-Pick disease with foamy and sea-blue histiocytes. Am ₹ Dis Child 1977;131:955-61.

12 Fried K, Beer S, Krespin HI, et al. Biochemical, genetic and ultrastructural study of a family with the sea-blue histiocyte syndrome/chronic non-neuropathic Niemann-Pick disease. Eur F Clin Invest 1978;8:249-53.

13 Dewhurst N, Besley GTN, Finlayson NDC, Parker AC. Sea blue histiocytosis in a patient with chronic non-neuropathic NiemannPick disease. $\mathcal{F}$ Clin Pathol 1979;32:1121-7.

14 Landas S, Foucar K, Sando GN, Ellefson R, Hamilton HE. Adult Niemann-Pick disease masquerading as sea-blue histiocyte syndrome: report of a case confirmed by lipid analysis and enzyme assays. Am 7 Hematol 1985;20:391-400.

15 Elleder M, Loida Z. Studies in lipid histochemistry. XII. Histochemical detection of sphingomyelin. Histochemie 1973 37:371-3.

16 Warnick GR, Nguyen T, Albers AA. Comparison of improved precipitation methods for quantification of high-density lipoprotein cholesterol. Clin Chem 1985;31:217-22.

17 Dulaney JT, Moser HW. Sulfatide lipidosis: metachromatic leukodystrophy. In: Stanbury JB, Wyngaarden JB, Fredrickson DS, eds. The metabolic basis of inherited disease, 4th ed. New York: McGraw-Hill, 1978:770-809.

18 Schneider EL, Pentchev PG, Hibbert SR, Sawitsky A, Brady RO. A new form of Niemann-Pick disease characterised by temperature-labile sphingomyelinase. $\mathcal{F}$ Med Genet 1978;15: $370-4$.

19 Lowry OH, Rosebrough NJ, Farr AL, Randall RJ. Protein measurement with the Folin phenol reagent. $f$ Biol Chem 1951;193:265-75. 
20 Herbert PN, Assmann G, Gotto AM Jr, Fredrickson DS. Familial lipoprotein deficiency: abetalipoproteinemia, hypobetalipoproteinemia and Tangier disease. In: Stanbury JB, Wyngaarden JB, Fredrickson DS, Goldstein JL, Brown MS, eds. The metabolic basis of inherited disease. 5th ed. New York: McGraw-Hill, 1983:589-621.

21 Brady RO. Sphingomyelin lipidosis: Niemann-Pick disease. In: Stanbury JB, Wyngaarden JB, Fredrickson DS, Goldstein JL, Brown MS, eds. The metabolic basis of inherited disease. 5th ed. New York: McGraw-Hill, 1983:831-41.

22 Vanier MT, Rousson R, Garcia I, et al. Biochemical studies in Niemann-Pick disease. III. In vitro and in vivo assays of sphingomyelin degradation in cultured skin fibroblasts and amniotic fluid cells for the diagnosis of the various forms of the disease. Clin Genet 1985;27:20-32.

23 Fredrickson DS. Sphingomyelin lipidosis: Niemann-Pick disease. In: Stanbury JB, Wyngaarden JB, Fredrickson DS, eds. The metabolic basis of inherited disease. 2nd ed. New York: McGrawHill, 1966:586-617.

24 Aubert I, Chanu B, Bakir R, et al. Histiocytes bleu de mer et maladies de surcharge. Trois observations. Ann Med Interne (Paris) 1985;136:133-6.

25 Reimers EG, Arguelles HA, Nieto LH, et al. Sindrome del histiocito azul marino: enfermedad de Niemann-Pick tipo B. Med Clin (Barc) 1986;86:644-6.

26 Day RC, Harry DS, Owen JS, Foo AY, McIntire N. Lecithincholesterol acyltransferase and the lipoprotein abnormalities of parenchymal liver disease. Clin Sci 1979;56:575-83.

27 Fredrickson DS. Familial high-density lipoprotein deficiency: Tangier disease. In: Stanbury JB, Wyngaarden JB, Fredrickson DS, eds. The metabolic basis of inherited disease. 2nd ed. New York: McGraw-Hill, 1966: 486-508.

28 Assmann G, Fredrickson DS. Acid lipase deficiency: Wolman's disease and cholesteryl ester storage disease. In: Stanbury JB, Wyngaarden JB, Fredrickson DS, Goldstein JL, Brown MS, eds. The metabolic basis of inherited disease. 5th ed. New York: McGraw-Hill, 1983:803-18.

29 Maziere JC, Maziere C, Gardette J, Mora L, Polonovsky J. Changes in cholesterol metabolism in cultured fibroblasts from patients with Niemann-Pick disease. Biochem Biophys Res Commun 1981;102:113-8.

30 Pentchev PG, Kruth HS, Comly ME, et al. Type C NiemannPick disease. A parallel loss of regulatory responses in both the uptake and esterification of low density lipoprotein-derived cholesterol in cultured fibroblasts. F Biol Chem 1986;261: 16775-80. 